\title{
PENGARUH PERBEDAAN FORMULASI TERHADAP SIFAT FISIK, KIMIA DAN ORGANOLEPTIK PADA MUFFIN NON TERIGU
}

\section{The Effect of Different Formulations Towards Physical, Chemical and Organoleptic Properties of Non Wheat Muffin}

\author{
Astien Iftahul Fauziyah*, Yunianta \\ Jurusan Teknologi Hasil Pertanian, FTP Universitas Brawijaya Malang \\ Jl. Veteran, Malang 65145 \\ *Penulis Korespondensi, Email: astien96@gmail.com
}

\begin{abstract}
ABSTRAK
Muffin adalah produk bakery yang tidak dapat dikonsumsi oleh semua orang karena adanya gluten dalam tepung terigu. Penanganan yang dapat dilakukan adalah dengan menggunakan formulasi non terigu seperti memanfaatkan tepung mocaf dan tepung ampas tahu serta kuning telur dan putih telur. Tujuan penelitian ini adalah untuk mengetahui pengaruh proporsi tepung mocaf, tepung ampas tahu, kuning telur dan putih telur pada pembuatan muffin non terigu. Penelitian ini menggunakan metode Rancangan Acak Kelompok dengan 9 formulasi $(F)$ dan diulang 3 kali. Data dianalisis dengan menggunakan ANOVA dan dilanjutkan dengan uji Tukey. Perlakuan terbaik diperoleh pada muffin dengan formulasi tepung mocaf $85 \mathrm{~g}$, tepung ampas tahu $15 \mathrm{~g}$, kuning telur $100 \mathrm{~g}$ dan putih telur $50 \mathrm{~g}$ dengan hasil $\left(\mathrm{L}^{*}\right)$ crust dan crumb sebesar $43.03 \pm 1.29$ dan $61.80 \pm 0.30$, ( $\mathrm{a}^{*}$ ) crust dan crumb sebesar $12.33 \pm 1.9$ dan $1.60 \pm 0.17,\left(b^{*}\right)$ crust dan crumb sebesar $10.50 \pm 0.53$ dan $31.93 \pm$ 2.37, tekstur $9.40 \pm 0.95$, porositas $\left(\mathrm{mm}^{2}\right) 5.94 \pm 0.04$, volume pengembangan (\%) $79.14 \pm$ 4.21, kadar air (\%) $19.01 \pm 1.36$, kadar serat (\%) $9.89 \pm 0.59$, kadar protein (\%) $7.77 \pm 0.68$, kadar lemak (\%) $27.68 \pm 3.34$, kadar abu (\%) $2.13 \pm 0.72$, serta total gula (\%) $1.18 \pm 0.08$.
\end{abstract}

Kata Kunci: Kuning Telur, Muffin, Putih Telur, Tepung Ampas Tahu, Tepung Mocaf

\section{ABSTRACT}

Muffin is a bakery produk that cannot be consumed by every person because of its gluten content in wheat flour. An alternative that can be done is by using a non wheat formulation like using modified cassava flour (mocaf), okara flour, egg yolk and egg white. This research aims to study the effect of mocaf, okara flour, egg yolk and egg white proportion in making non wheat muffins. The method used was Randomized Block Design with 9 formulations ( $F$ ) and was repeated 3 times. Data was analyzed using ANOVA and then followed by Tukey test. The best treatment was achieved with the formulation of $85 \mathrm{~g}$ mocaf, $15 \mathrm{~g}$ tepung ampas tahu, $100 \mathrm{~g}$ egg yolk and $50 \mathrm{~g}$ egg white with results crust and crumb $\left(L^{*}\right)$ as much as $43.03 \pm 1.29$ and $61.80 \pm 0.30$, crust and crumb $\left(a^{*}\right) 12.33 \pm 1.9$ and $1.60 \pm 0.17$, crust and crumb $\left(b^{*}\right) 0.50 \pm 0.53$ and $31.93 \pm 2.37$, texture value $9.40 \pm 0.95$, porosity $\left(\mathrm{mm}^{2}\right)$ $5.94 \pm 0.04$, volume expansion (\%) $79.14 \pm 4.21$, moisture content (\%) $19.01 \pm 1.36$, fiber content (\%) $9.89 \pm 0.59$, protein content (\%) $7.77 \pm 0.68$, fat content (\%) $27.68 \pm 3.34$, ash content (\%) $2.13 \pm 0.72$, and sugar content (\%) $1.18 \pm 0.08$.

Keywords: Egg Yolk, Muffin, Egg White, Okara Flour, Mocaf

\section{PENDAHULUAN}

Gandum dan tepung terigu merupakan salah satu komoditas impor di Indonesia. APTINDO (Asosiasi Produsen Tepung Terigu Indonesia) mengungkapkan bahwa impor 
gandum di Indonesia pada tahun 2018 diperkirakan mencapai 11.8 juta ton. Tingginya impor gandum disebabkan karena tepung gandum memiliki komponen khas terigu yaitu gluten yang tidak dimiliki oleh tepung non-terigu. Meskipun demikian, tidak semua orang dapat mengkonsumsi produk berbasis terigu. Lau et al., (2013) menyatakan bahwa gluten dapat menyebabkan alergi dan intoleransi pada penderita autis, atau disebut dengan celiac disease. Penanganan yang dapat dilakukan adalah dengan pembuatan produk bebas terigu. Salah satu produk bakery yang dapat diolah menjadi produk non terigu adalah muffin. Muffin tergolong sebagai quick bread yang dibuat dari tepung terigu dan seringkali ditambahkan buah atau kacang-kacangan.

Onyango et al. (2009) menemukan bahwa penggunaan 50\% pati singkong menghasilkan produk bakery dengan crumb dan tekstur yang bagus dibandingkan dengan penggunaan pati jagung, beras, dan pati kentang. Hal ini akan memperbaiki volume dan tekstur pada produk. Oleh karena itu, komoditas lokal, yaitu singkong, dapat dimanfaatkan untuk diolah menjadi modified cassava flour atau dengan istilah lain tepung mocaf. Namun, tepung mocaf memiliki kekurangan, yaitu kandungan protein yang rendah (1.2\%). Kekurangan tersebut dapat diatasi dengan memanfaatkan ampas tahu. Ampas tahu adalah hasil samping yang masih memiliki kandungan nutrisi yang tinggi. Ampas tahu basah yang dikeringkan dapat diolah menjadi tepung dan memiliki kandungan protein sebesar 17.72\% (Wati, 2013).

Selain faktor tepung, faktor telur juga mempengaruhi kualitas pada muffin non terigu. Dahlia (2014) menyatakan bahwa meskipun bagian telur memiliki peran masing-masing, lebih baik menggunakan telur utuh untuk menciptakan muffin yang lembut dan mengembang. Selama ini, penelitian mengenai proporsi antara kuning telur dan putih telur masih kurang. Oleh karena itu, pada penelitian ini memanfaatkan proporsi antara kuning telur dan putih telur untuk meningkatkan sifat pada muffin non terigu.

\section{BAHAN DAN METODE}

\section{Bahan}

Bahan baku yang digunakan adalah tepung mocaf yang diperoleh dari industri rumah tangga di daerah Malang. Sedangkan untuk tepung ampas tahu, ampas tahu yang digunakan untuk diolah menjadi tepung ampas tahu diperoleh dari salah satu UKM tahu di JI. Kendalsari No.1 Malang. Bahan pendukung seperti telur diperoleh dari pasar Blimbing sedangkan untuk gula, susu skim bubuk, minyak goreng, baking powder "cap Koepoe-Koepoe", dan cup muffin diperoleh dari toko "Primarasa" Malang.

Bahan yang digunakan untuk menganalisis adalah akuades, aseton-PA, tablet kjeldahl, $\mathrm{H}_{2} \mathrm{SO}_{4}$ pekat, $\mathrm{NaOH} 45 \%$, indikator pp, $\mathrm{HCl} 0,1 \mathrm{~N}$, petroleum eter-PA, alkohol $10 \%, \mathrm{HCl} 25 \%$, $\mathrm{H}_{3} \mathrm{BO}_{3} 3 \%$, indikator metilen merah, kertas saring halus dan aluminium foil.

\section{Alat}

Peralatan yang dibutuhkan untuk membuat muffin adalah timbangan analitik, baskom, sendok, kompor, tisu, oven listrik, loyang, solet/spatula plastik, cabinet dryer, dandang, sieve shaker 80 mesh, panci, thermometer, dan cetakan muffin.

Alat yang dibutuhkan dalam analisis adalah penggaris, kertas saring, spatula, aluminium foil, kertas label, kapas, corong, tisu, plastik, gelas beker, labu ukur, erlenmeyer, oven, cawan, timbangan analitik, pipet volume, pipet tetes, glassware, alat destilasi, desikator, pisau, kompor listrik, buret, labu lemak, soxhlet, refluks, labu kjedahl, lemari asam, shaker, texture analyzer, bulb dan color reader. 


\section{Desain Penelitian}

Tabel 1. Formulasi Pembuatan Muffin Non Terigu

\begin{tabular}{|c|c|c|c|c|c|c|c|c|c|}
\hline \multirow{2}{*}{ Bahan } & \multicolumn{7}{|c|}{ Jumlah } & \multirow[b]{2}{*}{ F8 } & \multirow[b]{2}{*}{ F9 } \\
\hline & F1 & F2 & F3 & F4 & F5 & F6 & F7 & & \\
\hline Tepung Mocaf (g) & 95 & 95 & 95 & 90 & 90 & 90 & 85 & 85 & 85 \\
\hline Tepung Ampas Tahu (g) & 5 & 5 & 5 & 10 & 10 & 10 & 15 & 15 & 15 \\
\hline Tepung Terigu & - & - & - & & - & - & - & - & - \\
\hline $\begin{array}{l}\text { Minyak goreng nabati } \\
\text { (g) }\end{array}$ & 45 & 45 & 45 & 45 & 45 & 45 & 45 & 45 & 45 \\
\hline Gula Halus (g) & 100 & 100 & 100 & 100 & 100 & 100 & 100 & 100 & 100 \\
\hline Kuning Telur (g) & 50 & 75 & 100 & 50 & 75 & 100 & 50 & 75 & 100 \\
\hline Putih Telur (g) & 100 & 75 & 50 & 100 & 75 & 50 & 100 & 75 & 50 \\
\hline Susu skim bubuk (g) & 30 & 30 & 30 & 30 & 30 & 30 & 30 & 30 & 30 \\
\hline Baking powder (g) & 1.5 & 1.5 & 1.5 & 1.5 & 1.5 & 1.5 & 1.5 & 1.5 & 1.5 \\
\hline Garam (g) & 1 & 1 & 1 & 1 & 1 & 1 & 1 & 1 & 1 \\
\hline Total $(\mathrm{g})$ & 427.5 & 427.5 & 427.5 & 427.5 & 427.5 & 427.5 & 427.5 & 427.5 & 427.5 \\
\hline
\end{tabular}

\section{Tahapan Penelitian}

\section{Proses Pembuatan Tepung Ampas Tahu}

Ampas tahu segar didapatkan dari UKM Malang. Lalu ampas tahu segar tersebut diperas agar sampel tidak terlalu basah. Setelah diperas, ampas tahu dikukus selama 15 menit pada suhu $100^{\circ} \mathrm{C}$. Setelah dikukus, ampas tahu dikeringkan dengan cabinet dryer suhu $55^{\circ} \mathrm{C}$ selama 8 jam. Ampas tahu kering dihaluskan dengan menggunakan blender. Ampas tahu yang sudah halus diayak dengan menggunakan ayakan ukuran 80 mesh.

\section{Proses Pembuatan Muffin Non Terigu}

Bahan-bahan yang diperlukan dalam pembuatan muffin ditimbang terlebih dahulu, antara lain tepung mocaf, tepung ampas tahu, telur, baking powder $1,5 \%$ (b/b total tepung), susu skim bubuk $30 \%$ (b/b total tepung), gula halus $100 \%$ (b/b total tepung), garam $1 \%$ (b/b total tepung), minyak goreng nabati $45 \%$ (b/b total tepung). Lalu, bahan kering dicampur dengan menggunakan solet plastik sebanyak 15-20 adukan. Telur dikocok dengan menggunakan whisk sampai berbuih dan minyak goreng nabati ditambahkan. Bahan kering dan bahan basah (telur dan minyak) dicampur dengan menggunakan solet plastik sebanyak 15-20 adukan. Adonan dimasukkan ke dalam cetakkan muffin sampai 3/4 penuh. Adonan dipanggang dalam oven selama 50 menit dengan suhu $180^{\circ} \mathrm{C}$.

\section{Metode}

Metode yang digunakan dalam penelitian ini adalah Rancangan Acak Kelompok (RAK), dimana terdapat 9 formulasi $(F)$ yang berbeda dengan 3 kali pengulangan. Perbedaan antara masing-masing formulasi adalah variasi proporsi tepung (tepung mocaf dan tepung ampas tahu) dan variasi bagian telur (kuning telur dan putih telur). Pengujian yang dilakukan berupa uji kimia, yaitu kadar air, kadar serat, kadar protein, kadar lemak, kadar abu, total gula dan kadar pati. Uji fisik juga dilakukan, yaitu warna, tekstur, volume pengembangan dan porositas. Lalu dilakukan uji organoleptik dengan parameter warna, aroma, tekstur, pori-pori, rasa dan keseluruhan atribut.

\section{HASIL DAN PEMBAHASAN}

\section{Karakteristik Bahan Baku}

Berdasarkan Tabel 2, dapat dilihat bahwa parameter penelitian meliputi sifat kimia dan fisik pada tepung ampas dan tepung mocaf yang digunakan dalam penelitian ini. Hasil uji $T$ menunjukkan perbedaan yang tidak nyata $(p>0.05)$ pada kadar air dan kadar serat untuk tepung ampas tahu. Hal tersebut menunjukkan bahwa perbedaan hasil jika dibandingkan dengan literatur tidak berbeda jauh. Hasil uji T menunjukkan perbedaan yang nyata $(p<0.05)$ pada kadar protein. Komposisi kimia pada ampas tahu akan bergantung dengan proses yang dilalui untuk mendapatkan ampas tahu (Ostermann, 2017), perbedaan kultivar kedelai, dan 
metode produksi (Li et al., 2012). Selain faktor-faktor diatas, sistem pengeringan untuk mendapatkan ampas tahu kering akan mempengaruhi komposisi kimia juga. Untuk tepung mocaf, hasil uji T menunjukkan perbedaan yang tidak nyata ( $p>0.05)$ pada kadar serat dan kadar protein sedangkan uji T menunjukkan perbedaan yang nyata $(p<0.05)$ terhadap kadar air dan kadar pati. Yulifianti dan Ginting (2011) menyatakan sifat fisik dan kimia ubi kayu sebagai bahan baku dapat menentukan kualitas tepung yang dihasilkan. Ubi kayu segar sesudah dipanen lebih dari 48 jam mudah rusak, yang dapat menyebabkan warna ubi dan kadar pati berubah. Selain itu, varietas ubi kayu yang digunakan ketika membuat tepung mocaf dapat menyebabkan kadar pati yang berbeda-beda.

Tabel 2. Komposisi Analisis Tepung Ampas Tahu dan Tepung Mocaf

\begin{tabular}{lcccc}
\hline \multirow{2}{*}{ Parameter (\%) } & \multicolumn{2}{c}{ Tepung Ampas Tahu } & \multicolumn{2}{c}{ Tepung Mocaf } \\
\cline { 2 - 5 } & $\begin{array}{c}\text { Hasil } \\
\text { Penelitian }\end{array}$ & $\begin{array}{c}\text { Literat } \\
\text { ur }\end{array}$ & $\begin{array}{c}\text { Hasil } \\
\text { Penelitian }\end{array}$ & Literatur \\
\hline a. $\quad \begin{array}{ccc}\text { Karakteristik Kimia } \\
\text { - Kadar Air }\end{array}$ & $10.42 \pm 2.04$ & $6.89^{\mathrm{d}}$ & $14.04 \pm 0.35$ & $11.51^{\mathrm{b}}$ \\
- Kadar Serat & $11.95 \pm 2.80$ & $15.46^{\mathrm{d}}$ & $4.48 \pm 1.08$ & $3.4^{\mathrm{c}}$ \\
- Kadar Protein & $15.98 \pm 0.13$ & $30.36^{\mathrm{e}}$ & $1.09 \pm 0.08$ & $1.2^{\mathrm{c}}$ \\
- Kadar Pati & - & - & $61.07 \pm 1.20$ & $78.76^{\mathrm{a}}$ \\
b. Karakteristik Fisik & & & & \\
- Warna & & & $89.00 \pm 0.62$ & \\
$\quad$ Nilai Kecerahan $\left(\mathrm{L}^{*}\right)$ & $84.27 \pm 2.14$ & & $-0.97 \pm 0.12$ & \\
Nilai Kemerahan (a*) & $0.83 \pm 0.23$ & & $12.10 \pm 0.26$ & \\
Nilai Kekuningan $\left(\mathrm{b}^{*}\right)$ & $17.20 \pm 0.78$ & & &
\end{tabular}

Keterangan: Wahjuningsih and Susanti $(2015)^{\mathrm{a}}$

Sulistyo and Nakahara (2014) ${ }^{\mathrm{b}}$

Salim (2011)

Grizotto et al. (2012) ${ }^{\mathrm{d}}$

Wickramarathna and Arampath (2003) ${ }^{\mathrm{e}}$

\section{Karakteristik Kimia}

\section{a. Kadar Air}

Tabel 3. Rerata Nilai Kadar Air pada Muffin Non Terigu

\begin{tabular}{|c|c|c|c|c|c|c|}
\hline \multirow[b]{2}{*}{ Formulasi } & \multicolumn{2}{|c|}{ Tepung (g) } & \multicolumn{2}{|c|}{ Telur (g) } & \multirow{2}{*}{$\begin{array}{l}\text { Rerata Nilai } \\
\text { Kadar Air (\%) }\end{array}$} & \multirow{2}{*}{$\begin{array}{l}\text { Nilai } \\
\text { Tukey }\end{array}$} \\
\hline & Mocaf & $\begin{array}{c}\text { Ampas } \\
\text { Tahu }\end{array}$ & Kuning & Putih & & \\
\hline F1 & 95 & 5 & 50 & 100 & $20.72 \pm 1.52 a b c$ & \\
\hline $\mathrm{F} 2$ & 95 & 5 & 75 & 75 & $18.90 \pm 2.01 \mathrm{bc}$ & \\
\hline F3 & 95 & 5 & 100 & 50 & $17.75 \pm 0.52 c$ & \\
\hline $\mathrm{F} 4$ & 90 & 10 & 50 & 100 & $21.86 \pm 0.63 a b$ & \\
\hline F5 & 90 & 10 & 75 & 75 & $19.56 \pm 1.81 \mathrm{abc}$ & 2.277 \\
\hline F6 & 90 & 10 & 100 & 50 & $18.30 \pm 2.11 \mathrm{c}$ & \\
\hline F7 & 85 & 15 & 50 & 100 & $22.28 \pm 1.03 \mathrm{a}$ & \\
\hline F8 & 85 & 15 & 75 & 75 & $20.39 \pm 1.38 a b c$ & \\
\hline F9 & 85 & 15 & 100 & 50 & $19.01 \pm 1.36 \mathrm{bc}$ & \\
\hline
\end{tabular}

Semakin meningkatnya proporsi tepung ampas tahu yang digunakan maka akan meningkatkan kadar air pada muffin non terigu. Hal ini dapat disebabkan oleh kandungan serat kasar dan protein yang tinggi pada tepung ampas tahu, yaitu sebesar $11.95 \%$ dan $15.98 \%$. Martin (2010), menyatakan bahwa kandungan protein dan serat kasar yang tinggi pada tepung ampas tahu dapat meningkatkan water holding capacity (WHC). Serat pada pangan, baik yang larut air maupun tidak larut air, dapat mengikat air melalui beberapa mekanisme, seperti interaksi ion dan ikatan hidrogen. Selain itu, pada suhu tinggi protein akan mudah terdenaturasi akibat putusnya ikatan hidrogen yang membentuk struktur heliks, 
kemudian protein akan berikatan dengan air. Interaksi antara protein dan air akan memberikan sifat hidrasi pada protein yaitu daya serap air. Semakin meningkatnya penggunaan kuning telur maka akan menurunkan kadar air pada muffin non terigu. Kadar air tertinggi terdapat pada formulasi kuning telur $50 \mathrm{~g}$ dan putih telur $100 \mathrm{~g}$. Hal ini dikarenakan protein pada telur memiliki water holding capacity (Martin, 2010). Berdasarkan pembahasan, kadar air pada muffin dapat dipengaruhi oleh perbedaan formula yang digunakan sehingga memiliki karakteristik pengikatan air yang berbeda pula (Hardiyanti, 2018).

\section{b. Kadar Serat}

\begin{tabular}{ccccccc}
\multicolumn{7}{c}{ Tabel 4. Rerata Nilai Kadar Serat Muffin Non Terigu } \\
\cline { 1 - 5 } Formulasi & \begin{tabular}{c} 
Tepung (g) \\
\cline { 2 - 5 }
\end{tabular} & $\begin{array}{c}\text { Mocaf } \\
\text { Ampas } \\
\text { Tahu }\end{array}$ & Kuning & Putih & $\begin{array}{c}\text { Rerata Nilai } \\
\text { Kadar Serat } \\
(\%)\end{array}$ & $\begin{array}{c}\text { Nilai } \\
\text { Tukey }\end{array}$ \\
\hline F1 & 95 & 5 & 50 & 100 & $5.52 \pm 0.61 \mathrm{c}$ & \\
F2 & 95 & 5 & 75 & 75 & $5.95 \pm 1.07 \mathrm{bc}$ & \\
F3 & 95 & 5 & 100 & 50 & $6.30 \pm 1.03 \mathrm{bc}$ & \\
F4 & 90 & 10 & 50 & 100 & $5.17 \pm 0.52 \mathrm{c}$ & \\
F5 & 90 & 10 & 75 & 75 & $6.17 \pm 0.87 \mathrm{c}$ & 1.772 \\
F6 & 90 & 10 & 100 & 50 & $8.39 \pm 0.44 \mathrm{ab}$ & \\
F7 & 85 & 15 & 50 & 100 & $5.82 \pm 0.24 \mathrm{c}$ & \\
F8 & 85 & 15 & 75 & 75 & $6.86 \pm 1.20 \mathrm{bc}$ & \\
F9 & 85 & 15 & 100 & 50 & $9.89 \pm 0.59 \mathrm{a}$ & \\
\hline
\end{tabular}

Peningkatan kadar serat dapat terjadi karena kandungan serat kasar pada tepung ampas tahu. Berdasarkan analisis bahan baku yang telah dilakukan, tepung ampas tahu memiliki serat kasar sebesar $11.95 \%$. Menurut Grizotto et al. (2012), kandungan serat kasar pada tepung ampas tahu bisa mencapai $15.46 \%$. Kandungan serat kasar tersebut akan mempengaruhi peningkatan kadar serat kasar pada muffin non terigu, karena semakin meningkatnya proporsi tepung ampas tahu yang ditambahkan maka secara signifikan akan meningkatkan kadar serat produk. Peningkatan kuning telur juga dapat meningkatkan kadar serat kasar pada muffin non terigu. Hal tersebut diduga telur memiliki sifat sebagai pengikat, yaitu mampu mengikat komponen bahan baku yang ada di dalamnya. Protein pada kuning telur dapat membentuk ikatan dengan serat kasar yang terdapat pada tepung ampas tahu dan tepung mocaf serta memperkuat ikatan tersebut.

\section{c. Kadar Protein}

Rerata nilai kadar protein terendah diperoleh pada formulasi 1 , yaitu $6.55 \%$. Rerata nilai kadar protein tertinggi diperoleh pada formulasi 9, yaitu 7.77\%. Kaspar (2005) menyatakan bahwa kandungan protein pada muffin dengan $100 \%$ tepung terigu adalah sebesar $6.14 \%$. Hasil analisis ragam menunjukkan bahwa perbedaan formulasi tidak memberikan pengaruh nyata $(\alpha=0.05)$ terhadap rerata nilai kadar protein muffin non terigu. Protein pada muffin non terigu ini dapat berasal dari tepung ampas tahu dan susu. Peningkatan kadar protein muffin non terigu disebabkan oleh bertambahnya tepung ampas tahu. Kadar protein pada tepung mocaf sangat rendah, yaitu sebesar $1.09 \%$ pada penelitian ini. Ketika proporsi tepung ampas tahu ditambahkan, kadar protein akan naik karena tepung ampas tahu memiliki kandungan protein sebesar 30.36\% (Wickramarathna and Arampath, 2003).

\section{d. Kadar Lemak}

Rerata kadar lemak mengalami kenaikan seiring dengan meningkatnya kuning telur. Hal tersebut dikarenakan kuning telur memiliki kandungan lemak yang tinggi, yaitu sebesar $32.5 \%$ (Vaclavik and Christian, 2008). Semakin banyak kuning telur yang ditambahkan maka semakin tinggi kadar lemak pada muffin. Selain itu, terdapat kemampuan pengikatan lemak oleh porsi molekul hidrofobik yang dimiliki lesitin pada kuning telur sehingga kadar lemak pada produk dapat meningkat. Kadar lemak yang tinggi pada produk ini juga dapat dipengaruhi oleh 
penggunaan minyak nabati pada masing-masing formulasi, yaitu sebanyak $45 \mathrm{~g}$. Oleh karena itu, kemampuan lesitin untuk mengikat dengan lemak akan menghasilkan muffin dengan kadar lemak yang semakin tinggi. Suhu dan waktu pemanasan memberikan efek pada kadar lemak produk. Pemberian panas yang tinggi pada lemak akan mengakibatkan terputusnya ikatan-ikatan rangkap pada lemak, sehingga lemak tersebut akan terdekomposisi menjadi gliserol dan asam lemak (Hardiyanti, 2018).

Tabel 5. Rerata Nilai Kadar Lemak Muffin Non Terigu

\begin{tabular}{|c|c|c|c|c|c|c|}
\hline \multirow[b]{2}{*}{ Formulasi } & \multicolumn{2}{|c|}{ Tepung (g) } & \multicolumn{2}{|c|}{ Telur $(\mathbf{g})$} & \multirow{2}{*}{$\begin{array}{c}\text { Rerata Nilai } \\
\text { Kadar Lemak } \\
(\%)\end{array}$} & \multirow{2}{*}{$\begin{array}{l}\text { Nilai } \\
\text { Tukey }\end{array}$} \\
\hline & Mocaf & $\begin{array}{c}\text { Ampas } \\
\text { Tahu }\end{array}$ & Kuning & Putih & & \\
\hline $\mathrm{F} 1$ & 95 & 5 & 50 & 100 & $19.29 \pm 222 b c$ & \\
\hline $\mathrm{F} 2$ & 95 & 5 & 75 & 75 & $21.55 \pm 5.43 \mathrm{abc}$ & \\
\hline F3 & 95 & 5 & 100 & 50 & $22.07 \pm 1.02 \mathrm{abc}$ & \\
\hline $\mathrm{F} 4$ & 90 & 10 & 50 & 100 & $17.81 \pm 1.04 \mathrm{c}$ & \\
\hline F5 & 90 & 10 & 75 & 75 & $20.04 \pm 1.60 \mathrm{bc}$ & 5.294 \\
\hline F6 & 90 & 10 & 100 & 50 & $25.99 \pm 3.00 \mathrm{ab}$ & \\
\hline F7 & 85 & 15 & 50 & 100 & $16.24 \pm 1.90 \mathrm{c}$ & \\
\hline F8 & 85 & 15 & 75 & 75 & $20.45 \pm 1.61 \mathrm{abc}$ & \\
\hline F9 & 85 & 15 & 100 & 50 & $27.68 \pm 3.34 a$ & \\
\hline
\end{tabular}

\section{e. Kadar Abu}

Rerata nilai kadar abu tertinggi diperoleh pada formulasi 9 , yaitu $2.13 \%$. Rerata nilai kadar abu terendah diperoleh pada formulasi 1, yaitu 1.24\%. Jika dibandingkan dengan SNI 01-3840 (1995), kadar serat untuk muffin non terigu pada penelitian ini melebihi syarat SNI untuk roti manis, yaitu kadar abu maksimal $1.00 \%$. Perbedaan ini dikarenakan kandungan abu pada tepung ampas tahu lebih tinggi jika dibandingkan dengan tepung terigu, yaitu sebesar $3.58 \%$ Selain itu, faktor bahan yang digunakan juga dapat mempengaruhi karena abu juga berasal dari bahan seperti margarin dan telur. Hasil analisis ragam menunjukkan bahwa perbedaan formulasi tidak memberikan pengaruh nyata $(\alpha=0.05)$ terhadap rerata nilai kadar abu muffin non terigu. Faktor-faktor yang mempengaruhi kadar abu bahan antara lain komposisi bahan, suhu pengabuan, lamanya pengabuan dan wadah pengabuannya.

\section{f. Total Gula}

Perbedaan formulasi tidak memberikan pengaruh nyata terhadap rerata total gula pada muffin. Hasil analisis ragam menunjukkan bahwa perbedaan formulasi tidak memberikan pengaruh nyata $(\alpha=0.05)$ terhadap rerata nilai total gula muffin non terigu. Hal ini sesuai dengan penelitian yang dilakukan oleh Yasa dkk. (2016) yang membuat roti manis, dimana literatur tersebut menyatakan bahwa formulasi tidak mempengaruhi terhadap kadar gula pada roti manis. Bahan yang dapat memberikan pengaruh pada total gula adalah gula pasir, namun pada penelitian ini jumlah gula pasir yang ditambahkan pada masing-masing perlakuan adalah sama yaitu sebesar $100 \mathrm{~g}$.

\section{Karakteristik Fisik}

\section{a. Warna}

Berdasarkan hasil analisis ragam, perbedaan formulasi memberikan pengaruh nyata $(\alpha=0,05)$ terhadap nilai kecerahan crust, kemerahan crust dan crumb serta kekuningan crust dan crumb. Penurunan nilai kecerahan menunjukkan bahwa warna mendekati hitam (0) atau semakin gelap warna pada permukaan. Hal ini dapat terjadi karena Ureta et al. (2014) menyatakan bahwa, ketika suhu pada permukaan melebihi $100^{\circ} \mathrm{C}$ maka reaksi browning akan teraktivasi sehingga warna pada permukaan akan menjadi lebih gelap. Browning ini dapat disebut dengan reaksi maillard, dimana terjadi reaksi non enzimatis antara gugus amino dan gula reduksi. Pada penelitian ini, kandungan protein pada tepung 
ampas tahu adalah sebesar $15.98 \%$. Kandungan protein ini dapat membantu terjadinya reaksi maillard, sehingga warna pada permukaan muffin akan menjadi lebih gelap dengan bertambahnya tepung ampas tahu. Levent and Bilgich (2011), menyatakan bahwa pada bagian crumb, suhu tidak mencapai $100^{\circ} \mathrm{C}$ ketika proses pemanggangan. Oleh karena itu, reaksi Maillard atau karamelisasi tidak akan teraktivisasi atau akan terjadi lebih lambat jika dibandingkan dengan bagian permukaan muffin. Stadelmen and Cotterill (1995), menyatakan bahwa kuning telur memberikan warna kuning pada berbagai jenis makanan terutama untuk makanan bakery. Kuning telur memiliki pigmen alami yaitu xantofil yang merupakan suatu karotenoid dengan pigmen kuning-oranye

Tabel 6. Rerata Nilai L* pada Permukaan Muffin Non Terigu

\begin{tabular}{|c|c|c|c|c|c|c|}
\hline \multirow{2}{*}{ Formulasi } & \multicolumn{2}{|c|}{ Tepung (g) } & \multicolumn{2}{|c|}{ Telur (g) } & \multirow{2}{*}{$\begin{array}{c}\text { Rerata Nilai } \\
\text { Kecerahan }\left(L^{\star}\right)\end{array}$} & \multirow{2}{*}{$\begin{array}{l}\text { Nilai } \\
\text { Tukey }\end{array}$} \\
\hline & Mocaf & Ampas Tahu & Kuning & Putih & & \\
\hline F1 & 95 & 5 & 50 & 100 & $62.27 \pm 1.63 \mathrm{a}$ & \\
\hline $\mathrm{F} 2$ & 95 & 5 & 75 & 75 & $48.73 \pm 0.64 b c$ & \\
\hline F3 & 95 & 5 & 100 & 50 & $43.07 \pm 1.69 c$ & \\
\hline F4 & 90 & 10 & 50 & 100 & $54.30 \pm 3.38 \mathrm{ab}$ & \\
\hline F5 & 90 & 10 & 75 & 75 & $48.50 \pm 4.88 \mathrm{bc}$ & 5.787 \\
\hline F6 & 90 & 10 & 100 & 50 & $43.37 \pm 4.25 c$ & \\
\hline F7 & 85 & 15 & 50 & 100 & $50.07 \pm 0.90 \mathrm{bc}$ & \\
\hline F8 & 85 & 15 & 75 & 75 & $44.63 \pm 0.15 c$ & \\
\hline F9 & 85 & 15 & 100 & 50 & $43.03 \pm 1.79 c$ & \\
\hline
\end{tabular}

Tabel 7. Rerata Nilai a* pada Permukaan Muffin Non Terigu

\begin{tabular}{|c|c|c|c|c|c|c|}
\hline \multirow{2}{*}{ Formulasi } & \multicolumn{2}{|c|}{ Tepung (g) } & \multicolumn{2}{|c|}{ Telur $(\mathrm{g})$} & \multirow{2}{*}{$\begin{array}{c}\text { Rerata Nilai } \\
\text { Kemerahan } \\
\left(\mathbf{a}^{*}\right)\end{array}$} & \multirow{2}{*}{$\begin{array}{l}\text { Nilai } \\
\text { Tukey }\end{array}$} \\
\hline & Mocaf & Ampas Tahu & Kuning & Putih & & \\
\hline $\mathrm{F} 1$ & 95 & 5 & 50 & 100 & $6.10 \pm 1.65 b$ & \\
\hline $\mathrm{F} 2$ & 95 & 5 & 75 & 75 & $8.97 \pm 1.64 \mathrm{ab}$ & \\
\hline F3 & 95 & 5 & 100 & 50 & $12.97 \pm 2.49 \mathrm{a}$ & \\
\hline $\mathrm{F} 4$ & 90 & 10 & 50 & 100 & $9.00 \pm 1.37 \mathrm{ab}$ & \\
\hline F5 & 90 & 10 & 75 & 75 & $10.63 \pm 0.71 \mathrm{ab}$ & 3.512 \\
\hline F6 & 90 & 10 & 100 & 50 & $11.20 \pm 1.04 \mathrm{a}$ & \\
\hline $\mathrm{F} 7$ & 85 & 15 & 50 & 100 & $8.40 \pm 1.42 a b$ & \\
\hline F8 & 85 & 15 & 75 & 75 & $9.67 \pm 1.27 \mathrm{ab}$ & \\
\hline F9 & 85 & 15 & 100 & 50 & $12.33 \pm 1.90 \mathrm{a}$ & \\
\hline
\end{tabular}

Tabel 8. Rerata Nilai a* pada Crumb Muffin Non Terigu

\begin{tabular}{|c|c|c|c|c|c|c|}
\hline \multirow{2}{*}{ Formulasi } & \multicolumn{2}{|c|}{ Tepung (g) } & \multicolumn{2}{|c|}{ Telur (g) } & \multirow{2}{*}{$\begin{array}{c}\text { Rerata Nilai } \\
\text { Kemerahan }\left(a^{\star}\right)\end{array}$} & \multirow{2}{*}{$\begin{array}{l}\text { Nilai } \\
\text { Tukey }\end{array}$} \\
\hline & Mocaf & Ampas Tahu & Kuning & Putih & & \\
\hline F1 & 95 & 5 & 50 & 100 & $0.30 \pm 0.200 c$ & \\
\hline $\mathrm{F} 2$ & 95 & 5 & 75 & 75 & $0.93 \pm 0.21 \mathrm{abc}$ & \\
\hline F3 & 95 & 5 & 100 & 50 & $1.00 \pm 1.00 a b c$ & \\
\hline F4 & 90 & 10 & 50 & 100 & $0.67 \pm 0.67 \mathrm{bc}$ & \\
\hline F5 & 90 & 10 & 75 & 75 & $1.13 \pm 1.13 \mathrm{ab}$ & 0.576 \\
\hline F6 & 90 & 10 & 100 & 50 & $1.47 \pm 1.47 \mathrm{a}$ & \\
\hline F7 & 85 & 15 & 50 & 100 & $0.87 \pm 0.87 a b c$ & \\
\hline F8 & 85 & 15 & 75 & 75 & $1.30 \pm 1.30 a b$ & \\
\hline F9 & 85 & 15 & 100 & 50 & $1.60 \pm 1.60 \mathrm{a}$ & \\
\hline
\end{tabular}


Tabel 9. Rerata Nilai $b^{*}$ pada Permukaan Muffin Non Terigu

\begin{tabular}{|c|c|c|c|c|c|c|}
\hline \multirow{2}{*}{ Formulasi } & \multicolumn{2}{|c|}{ Tepung (g) } & \multicolumn{2}{|c|}{ Telur (g) } & \multirow{2}{*}{$\begin{array}{l}\text { Rerata Nilai } \\
\text { Kekuningan } \\
\left(\mathbf{b}^{\star}\right)\end{array}$} & \multirow{2}{*}{$\begin{array}{l}\text { Nilai } \\
\text { Tukey }\end{array}$} \\
\hline & Mocaf & Ampas Tahu & Kuning & Putih & & \\
\hline F1 & 95 & 5 & 50 & 100 & $30.87 \pm 1.32 \mathrm{a}$ & \\
\hline $\mathrm{F} 2$ & 95 & 5 & 75 & 75 & $20.38 \pm 1.17 \mathrm{~cd}$ & \\
\hline F3 & 95 & 5 & 100 & 50 & $12.53 \pm 1.24 \mathrm{fg}$ & \\
\hline $\mathrm{F} 4$ & 90 & 10 & 50 & 100 & $24.80 \pm 1.93 b$ & \\
\hline F5 & 90 & 10 & 75 & 75 & $17.23 \pm 2.71 \mathrm{de}$ & 2.927 \\
\hline F6 & 90 & 10 & 100 & 50 & $10.83 \pm 0.67 \mathrm{~g}$ & \\
\hline F7 & 85 & 15 & 50 & 100 & $22.10 \pm 0.66 \mathrm{bc}$ & \\
\hline F8 & 85 & 15 & 75 & 75 & $15.37 \pm 1.02$ ef & \\
\hline F9 & 85 & 15 & 100 & 50 & $10.50 \pm 0.53 \mathrm{~g}$ & \\
\hline \multicolumn{7}{|c|}{ Tabel 10. Rerata Nilai b* pada Crumb Muffin Non Terigu } \\
\hline \multirow{2}{*}{ Formulasi } & \multicolumn{2}{|c|}{ Tepung (g) } & \multicolumn{2}{|c|}{ Telur (g) } & \multirow{2}{*}{$\begin{array}{c}\text { Rerata Nilai } \\
\begin{array}{c}\text { Kekuningan } \\
\left(b^{\star}\right)\end{array}\end{array}$} & \multirow{2}{*}{$\begin{array}{l}\text { Nilai } \\
\text { Tukey }\end{array}$} \\
\hline & Mocaf & Ampas Tahu & Kuning & Putih & & \\
\hline F1 & 95 & 5 & 50 & 100 & $22.53 \pm 1.89 \mathrm{e}$ & \\
\hline $\mathrm{F} 2$ & 95 & 5 & 75 & 75 & $28.00 \pm 0.95 \mathrm{abc}$ & \\
\hline F3 & 95 & 5 & 100 & 50 & $29.20 \pm 0.87 \mathrm{ab}$ & \\
\hline $\mathrm{F} 4$ & 90 & 10 & 50 & 100 & $23.73 \pm 2.27 \mathrm{de}$ & \\
\hline F5 & 90 & 10 & 75 & 75 & $27.27 \pm 0.96 \mathrm{bcd}$ & 3.025 \\
\hline F6 & 90 & 10 & 100 & 50 & $29.37 \pm 0.91 \mathrm{ab}$ & \\
\hline F7 & 85 & 15 & 50 & 100 & $24.00 \pm 0.95 \mathrm{cde}$ & \\
\hline F8 & 85 & 15 & 75 & 75 & $29.13 \pm 0.40 a b$ & \\
\hline F9 & 85 & 15 & 100 & 50 & $31.93 \pm 2.37 \mathrm{a}$ & \\
\hline
\end{tabular}

\section{b. Tekstur}

Tabel 11. Rerata Nilai Tekstur pada Muffin Non Terigu

\begin{tabular}{|c|c|c|c|c|c|c|}
\hline \multirow{2}{*}{ Formulasi } & \multicolumn{2}{|c|}{ Tepung (g) } & \multicolumn{2}{|c|}{ Telur $(\mathbf{g})$} & \multirow{2}{*}{$\begin{array}{c}\text { Rerata Nilai } \\
\text { Kekerasan (N) }\end{array}$} & \multirow{2}{*}{$\begin{array}{l}\text { Nilai } \\
\text { Tukey }\end{array}$} \\
\hline & Mocaf & Ampas Tahu & Kuning & Putih & & \\
\hline F1 & 95 & 5 & 50 & 100 & $11.53 \pm 0.35 \mathrm{a}$ & \\
\hline F2 & 95 & 5 & 75 & 75 & $9.20 \pm 0.79 a b c$ & \\
\hline F3 & 95 & 5 & 100 & 50 & $9.80 \pm 0.66 \mathrm{abc}$ & \\
\hline F4 & 90 & 10 & 50 & 100 & $11.07 \pm 0.91 \mathrm{ab}$ & \\
\hline F5 & 90 & 10 & 75 & 75 & $8.43 \pm 0.92 b c$ & 2.147 \\
\hline F6 & 90 & 10 & 100 & 50 & $8.03 \pm 0.81 c$ & \\
\hline F7 & 85 & 15 & 50 & 100 & $11.37 \pm 1.72 \mathrm{ab}$ & \\
\hline F8 & 85 & 15 & 75 & 75 & $11.23 \pm 1.95 \mathrm{ab}$ & \\
\hline F9 & 85 & 15 & 100 & 50 & $9.40 \pm 0.95 a b c$ & \\
\hline
\end{tabular}

Nilai kekerasan tertinggi terdapat pada perlakuan formulasi dengan penggunaan tepung mocaf $85 \mathrm{~g}$ dan tepung ampas tahu $15 \mathrm{~g}$, lalu terjadi penurunan pada formulasi dengan penggunaan tepung mocaf $90 \mathrm{~g}$ dan tepung ampas tahu $10 \mathrm{~g}$ dan terjadi kenaikan kembali pada formulasi yang menggunakan tepung mocaf $95 \mathrm{~g}$ dan tepung ampas tahu $5 \mathrm{~g}$. Hasil tersebut menunjukkan bahwa muffin dengan tepung mocaf $95 \mathrm{~g}$ dan tepung ampas tahu $5 \mathrm{~g}$ lebih keras dibandingkan dengan tepung mocaf $90 \mathrm{~g}$ dan tepung ampas tahu $10 \mathrm{~g}$. Hal ini tidak sesuai dengan literatur, yaitu Martin (2010) yang menyatakan bahwa penambahan tepung ampas tahu akan menyebabkan suatu produk menjadi lebih viscous dengan tekstur yang lebih keras. Tepung ampas tahu memiliki kandungan protein dan serat yang tinggi sehingga water holding capacity akan meningkat. Semakin tinggi water holding capacity maka semakin banyak air bebas yang terikat oleh serat kasar sehingga dihasilkan tekstur muffin yang lebih kokoh dan kekerasan yang lebih tinggi. Ketidaksesuaian dapat disebabkan oleh 
adanya kadar pati yang terkandung dalam tepung mocaf. Semakin tinggi kandungan pati maka kandungan amilosa juga semakin meningkat. Amilosa pada pati cenderung menghasilkan produk yang lebih keras karena granula pati yang tersusun atas amilosa memiliki struktur yang lurus, komposisi granula lebih padat dan kompak sehingga pada saat pemanggangan proses mekarnya terjadi secara terbatas (Rauf, 2015).

Semakin tinggi penggunaan kuning telur maka nilai kekerasan muffin non terigu akan semakin menurun. Hal ini dapat terjadi karena kandungan lemak yang semakin meningkat. Hardiyanti (2018), menyatakan bahwa kandungan protein, lemak, suhu pengolahan dan kadar air dapat mempengaruhi tekstur pada muffin. Lemak pada kuning telur mengandung pengemulsi fosfolipid, yaitu lesitin, sehingga memiliki kemampuan mengemulsi. Kemampuan ini dapat meningkatkan aerasi dan menjaga stabilitas gelembung udara ketika proses pemanggangan sehingga bisa membuat tekstur lebih lembut (Movahhed et al., 2016). Sedangkan putih telur memiliki fungsi dalam pembentukan struktur adonan selama proses pemanggangan karena kemampuannya menangkap udara pada saat adonan dikocok. Putih telur membentuk struktur yang kokoh dan keras karena kandungan protein yang tinggi.

\section{c. Porositas}

\begin{tabular}{|c|c|c|c|c|c|c|}
\hline \multirow{2}{*}{ Formulasi } & \multicolumn{2}{|c|}{ Tepung (g) } & \multicolumn{2}{|c|}{ Telur $(g)$} & \multirow{2}{*}{$\begin{array}{c}\text { Rerata Nilai } \\
\text { Porositas } \\
\left(\mathrm{mm}^{2}\right)\end{array}$} & \multirow{2}{*}{$\begin{array}{c}\text { Nilai } \\
\text { Tukey }\end{array}$} \\
\hline & Mocaf & Ampas Tahu & Kuning & Putih & & \\
\hline F1 & 95 & 5 & 50 & 100 & $3.36 \pm 0.30 c$ & \\
\hline $\mathrm{F} 2$ & 95 & 5 & 75 & 75 & $3.64 \pm 0.40 \mathrm{bc}$ & \\
\hline F3 & 95 & 5 & 100 & 50 & $3.89 \pm 0.15 a b c$ & \\
\hline $\mathrm{F} 4$ & 90 & 10 & 50 & 100 & $4.13 \pm 0.65 \mathrm{abc}$ & \\
\hline F5 & 90 & 10 & 75 & 75 & $4.42 \pm 1.31 \mathrm{abc}$ & 1.360 \\
\hline F6 & 90 & 10 & 100 & 50 & $4.88 \pm 0.71 \mathrm{abc}$ & \\
\hline F7 & 85 & 15 & 50 & 100 & $4.42 \pm 0.72 \mathrm{abc}$ & \\
\hline F8 & 85 & 15 & 75 & 75 & $5.30 \pm 0.52 \mathrm{ab}$ & \\
\hline F9 & 85 & 15 & 100 & 50 & $5.94 \pm 0.04 \mathrm{a}$ & \\
\hline
\end{tabular}

Semakin tinggi tepung ampas tahu yang ditambahkan, maka nilai porositas akan semakin meningkat. Ketika adonan dipanaskan, granula pati akan menyerap air, membengkak, mengalami gelatinisasi dan sifat semi-crystallin akan menghilang. Gelatinisasi pati pada crumb akan membentuk struktur yang porous (Onyango, 2009). Muffin dengan kandungan pati tinggi dapat membentuk pori-pori lebih banyak. Hasil yang didapatkan tidak sesuai dengan literatur karena diduga pembengkakan pati dan hilangnya struktur granula dibatasi oleh kandungan air yang terbatas serta persaingan antara pati dengan komponen non pati yang berasal dari bahan lain untuk mengikat dengan kandungan air yang ada (Onyango, 2009). Semakin tinggi kuning telur yang ditambahkan, maka nilai porositas akan semakin meningkat. Mousia et al. (2007), menyatakan bahwa komponen lesitin yang terkandung dalam lemak kuning telur berperan dalam menjaga dan melindungi gas-gas yang dapat meningkatkan pengembangan adonan dan ukuran pori.

\section{d. Volume Pengembangan}

Semakin tinggi tepung ampas tahu yang ditambahkan maka volume pengembangan muffin non terigiu akan semakin menurun. Hal ini dikarenakan pada tepung mocaf terdapat kandungan pati yang cukup tinggi. Dalam pembuatan muffin non terigu, gelatinisasi selama pemanggangan memiliki peran yang signifikan dalam pembentukan struktur produk. Namun, gelatinisasi tidak terjadi untuk semua jenis produk, dan bergantung dengan ketersediaan air pada produk. Jika ketersediaan air sangat rendah maka terdapat persaingan untuk pati agar dapat mengikat air tersebut sehingga gelatinisasi tidak dapat terjadi secara signifikan hingga dapat menyebabkan pengembangan yang kurang (Le-Bail et al., 2018). Semakin tinggi penggunaan kuning telur, maka volume pengembangan akan semakin menurun. Martin (2010), menyatakan bahwa pengembangan volume dapat terjadi karena adanya protein telur 
dalam adonan, yang menyebabkan muffin memiliki struktur yang kuat dalam oven, memerangkap gelembung udara selama pemanggangan sehingga meningkatkan tinggi pada produk. Sakiyan et al. (2004), menyatakan bahwa pengemulsi memiliki kemampuan untuk mengikat bahan menjadi satu, membuat emulsi oil in water dan membantu memerangkap gelembung udara dalam adonan. Emulsi oil in water dapat membuat dinding yang stabil disekeliling gelembung udara.

Tabel 13. Rerata Nilai Volume Pengembangan pada Muffin Non Terigu

\begin{tabular}{ccccccc}
\hline \multirow{2}{*}{ Formulasi } & \multicolumn{2}{c}{ Tepung (g) } & \multicolumn{2}{c}{ Telur (g) } & $\begin{array}{c}\text { Rerata Nilai Volume } \\
\text { Pengembangan (\%) }\end{array}$ & $\begin{array}{c}\text { Nilai } \\
\text { Tukey }\end{array}$ \\
\cline { 2 - 6 } & Mocaf & Ampas Tahu & Kuning & Putih & Pem & \\
F1 & 95 & 5 & 50 & 100 & $91.71 \pm 1.00 \mathrm{a}$ & \\
F2 & 95 & 5 & 75 & 75 & $87.33 \pm 0.87 \mathrm{abc}$ & \\
F3 & 95 & 5 & 100 & 50 & $84.62 \pm 1.53 \mathrm{abc}$ & \\
F4 & 90 & 10 & 50 & 100 & $90.76 \pm 5.87 \mathrm{ab}$ & \\
F5 & 90 & 10 & 75 & 75 & $86.10 \pm 4.27 \mathrm{abc}$ & 6.392 \\
F6 & 90 & 10 & 100 & 50 & $83.62 \pm 1.65 \mathrm{abc}$ & \\
F7 & 85 & 15 & 50 & 100 & $84.09 \pm 1.90 \mathrm{abc}$ & \\
F8 & 85 & 15 & 75 & 75 & $82.38 \pm 0.44 \mathrm{bc}$ & \\
F9 & 85 & 15 & 100 & 50 & $79.14 \pm 4.21 \mathrm{c}$ & \\
\hline
\end{tabular}

\section{Karakteristik Organoleptik}

Berdasarkan uji Friedman, perbedaan formulasi memberikan pengaruh yang nyata terhadap parameter warna, aroma, pori, tekstur, rasa dan keseluruhan atribut dengan $p$-value sebesaar 0.00. Untuk parameter warna, formulasi 3 menghasilkan warna muffin non terigu dengan tingkat kesukaan tertinggi, sedangkan perlakuan formulasi 7 menghasilkan warna muffin non terigu dengan tingkat kesukaan terendah, yaitu sebesar 3.93 dan 2.87. Untuk parameter aroma, formulasi 6 menghasilkan aroma muffin non terigu dengan tingkat kesukaan tertinggi, sedangkan formulasi 7 menghasilkan aroma muffin non terigu dengan tingkat kesukaan terendah, yaitu sebesar 3.67 dan 3.22. Untuk parameter pori, formulasi 3 menghasilkan pori muffin non terigu dengan tingkat kesukaan tertinggi, sedangkan formulasi 1 menghasilkan pori muffin non terigu dengan tingkat kesukaan terendah, yaitu sebesar 3.48 dan 3.13. Untuk parameter tekstur, perlakuan formulasi 3 menghasilkan tekstur muffin non terigu dengan tingkat kesukaan tertinggi, sedangkan perlakuan formulasi 1 menghasilkan tekstur muffin non terigu dengan tingkat kesukaan terendah, yaitu sebesar 3.25 dan 2.55. Untuk parameter rasa, formulasi 3 menghasilkan rasa muffin non terigu dengan tingkat kesukaan tertinggi, sedangkan perlakuan formulasi 7 menghasilkan rasa muffin non terigu dengan tingkat kesukaan terendah, yaitu sebesar 3.67 dan 2.95. Untuk parameter keseluruhan atribut, formulasi 3 menghasilkan keseluruhan muffin non terigu dengan tingkat kesukaan tertinggi, sedangkan perlakuan formulasi 7 menghasilkan keseluruhan muffin non terigu dengan tingkat kesukaan terendah, yaitu sebesar 3.65 dan 3.03 .

\section{Perlakuan Terbaik}

Berdasarkan hasil perhitungan nilai perlakuan terbaik, didapatkan muffin non terigu perlakuan terbaik terhadap sifat kimia, fisik dan organoleptik yaitu pada formulasi 9 (tepung mocaf $85 \mathrm{~g}$, tepung ampas tahu $5 \mathrm{~g}$, kuning telur 100 , putih telur $50 \mathrm{~g}$ ). 
Tabel 14. Karakteristik pada Muffin Non Terigu Perlakuan Terbaik

\begin{tabular}{lc}
\hline Parameter & Muffin Non Terigu Perlakuan Terbaik \\
\hline Kecerahan $\left(\mathrm{L}^{*}\right)$ & \\
$-\quad$ Crust & $43.03 \pm 1.29$ \\
$-\quad$ Crumb & $61.80 \pm 0.30$ \\
Kemerahan $\left(\mathrm{a}^{*}\right)$ & \\
$-\quad$ Crust & $12.33 \pm 1.9$ \\
$-\quad$ Crumb & $1.60 \pm 0.17$ \\
Kekuningan (b*) & \\
$-\quad$ Crust & $10.50 \pm 0.53$ \\
$-\quad$ Crumb & $31.93 \pm 2.37$ \\
Tekstur & $9.40 \pm 0.95$ \\
Porositas & $5.94 \pm 0.04$ \\
Volume Pengembangan (\%) & $79.14 \pm 4.21$ \\
Kadar Air (\%) & $19.01 \pm 1.36$ \\
Kadar Serat (\%) & $9.89 \pm 0.59$ \\
Kadar Protein (\%) & $7.77 \pm 0.68$ \\
Kadar Lemak (\%) & $27.68 \pm 3.34$ \\
Kadar Abu (\%) & $2.13 \pm 0.72$ \\
Total Gula (\%) & $1.18 \pm 0.08$ \\
\hline
\end{tabular}

\section{SIMPULAN}

Berdasarkan penelitian yang telah dilakukan dapat disimpulkan bahwa perlakuan perbedaan formulasi berpengaruh nyata terhadap parameter rasa, aroma, warna, pori, tekstur dan keseluruhan atribut organoleptik. Perlakuan perbedaan formulasi berpengaruh nyata ( $\alpha$ $=0.05)$ terhadap kadar air, kadar serat, kadar lemak, kecerahan $\left(\mathrm{L}^{*}\right)$ crust, kemerahan $\left(\mathrm{a}^{*}\right)$ crust dan crumb, kekuningan $\left(\mathrm{b}^{*}\right)$ crust dan crumb, tekstur, porositas, serta volume pengembangan. Perlakuan terbaik diperoleh pada muffin non terigu dengan formulasi tepung mocaf $85 \mathrm{~g}$, tepung ampas tahu $15 \mathrm{~g}$, kuning telur $100 \mathrm{~g}$ dan putih telur $50 \mathrm{~g}$ berdasarkan parameter fisik, kimia dan organoleptik.

\section{DAFTAR PUSTAKA}

APTINDO (Asosiasi Produsen Tepung Terigu Indonesia). 2012. http://www.APTINDO.or.id/index.php?option=com_content\&view=article\&id=111:per 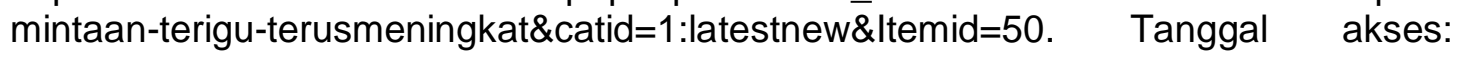 $21 / 02 / 2018$

Badan Standarisasi Nasional. 2011. Standar Nasional Indonesia Roti Manis SNI 01-38401995. Jakarta

Dahlia, L. 2014. Hidup Sehat Tanpa Gluten. Elex Media Komputindo. Gramedia Press. Jakarta

Grizotto, R., Andrade, J., Miyagusku, L. and Yamada, E. 2012. Physical, Chemical, Technological and Sensory Characteristics of Frankfurter Type Sausage Containing Okara Flour. Ciêcia e Tecnologia de Alimentos 32:3, 538-546

Hardiyanti, S. 2018. Analisis Kandungan Zat Gizi Muffin Ubi Jalar Kuning sebagai Alternatif Perbaikan Gizi Masyarakat. Skripsi. Universitas Islam Negeri Alauddin. Makassar

Kaspar, K. and Majoni, S. 2005. Functional Foods: A Comparison of Blueberry Muffin Ingredients. Journal of Student Research 40-41

Lau, N., Green,P., Taylor, A., et al. 2013. Markers of Celiac Disease and Gluten Sensitivity in Children with Autism. PloS One 8:6, e66155

Le-Bail, P., Hesso, N. and Le-Bail, A. 2018. Starch in Baked Products. Elsevier. France

Levent, H. and Bilgich, N. 2011. Effect of Gluten Free Flours on Physical Properties of Cakes. Journal of Food Science and Engineering 1, 354-360 
Li, B., Qiao, M., and Lu, F. 2012. Composition, Nutrition, and Utilization of Okara (Soybean Residu). Food Reviews International 28:3 231-232

Martin, T. 2010. Development of Okara Powder as A Gluten Free Alternative to All Purpose Flour for Value Added Use in Baked Goods. Thesis. Maryland

Mousia, Z., Campbell, G., Pandiella, S., and Web, B. 2007. Effect of Fat Level, Mixing Pressure and Temperature on Dough Expansion Capacity Druing Proving. Journal of Cereal Science 46, 139-147

Movahhed, M., Mohebbi, M., Koocheki, A., and Milani, E. 2016. The Effect of Different Emulsifiers on the Eggless Cake Properties Containing WPC. J. Food Science Technology 53:11, 3894-3903

Onyango, C., Mutungi, C., Unbehend, G., and Lindhauer, M. 2009. Creep Recovery Parameters of Gluten-Free Batter and Crumb Properties of Bread Prepared from Pregelatinized Cassva Starch, Sorghu, and Selected Proteins. Intl.J.Food.Sci.Technol 44, 2493-2499

Ostermann, M. 2017. Effect of Okara Flour Addition on the Physical and Sensory Quality of Wheat Bread. MOJ Food Processing \& Technology. 4:6, 3-7

Rauf, R. 2015. Kimia Pangan. Yogyakarta C.V Andi Offset

Sakiyan, O., Sumnu, G., and Sahin, S. 2004. Influence of Fat Content and Emulsifier Type on the Rheological Properties of Cake Batter. Eur Food Res Technol 219, 635-638

Salim, E. 2011. Mengolah Singkong Menjadi Tepung Mocaf Bisnis Produk Alterntif Pengganti Terigu. Yogyakarta. Lily Publisher

Stadelmen, W. and Cotterill, O. 1995. Egg Science and Technology. Haworth Press. New York

Sulistyo, J. and Nakahara, K. 2014. Cassava Flour Modification by Microorganism. Conference Paper. University Malaysia Sabah. Kinabalu, Malaysia

Ureta, M., Olivera, D., and Salvadori, V. 2014. Quality Attributes of Muffins: Effect of Baking Operative Conditions. Food Bioprocess Technol 7, 463-465

Vaclavik, V. and Christian, E. 2008. Essentials of Food Science. Springer. New York

Wahjuningsih, S. and Susanti, S. 2015. Chemical, Physical, and Sensory Characteristics of Analog Rice Developed from the Mocaf, Arrowroof, and Red Bean Flour. Earth Environment Science 102, pg. 4

Wickramarathna, G. and Arampath, P. 2003. Utilization of Okara in Bread Making. J. Sci (Bio.Sci.) 31, 29-33

Yasa, I., Zainuri, Zaini, M., dan Hadi, T. 2016. Mutu Roti Berbahan Dasar Mocaf: Formulasi dan Metode Pembuatan Adonan. Jurnal IImu dan Teknologi Pangan 2:2, 6-7

Yulifianti, R. dan Ginting, E. 2011. Karakteristik Tepung Mocaf dari Beberapa Varietas Ubi Kayu. Prosiding Seminar Hasil Penelitian Tanaman Aneka Kacang dan Umbi, Balitkabi, 623 